DOI: 10.17707/AgricultForest.63.4.21

\author{
Maryam POURKARIMI, Shahla MAHMOUDI, \\ Mohamadhasan MASIHABADI, Ebrahim PAZIRA, Abolfazl MOEINI ${ }^{1}$
}

\title{
USE OF MPSIAC AND EPM TO ESTIMATE SEDIMENT YIELD AND EROSION - A CASE STUDY OF A WATERSHED OF THE SECOND URBAN PHASE, MASHHAD, KHORASAN PROVINCE
}

\begin{abstract}
SUMMARY
The study area of Mashhad-Chenaran, measuring 223989.7 acres, is the largest and most important subbasin of Kashafrood. This area consists mostly of mountains and plains with variable slopes. The study area is an uneven land type and thus prone to soil erosion. Various practical methods have been developed to study soil erosion both qualitatively and quantitatively, but most of them do not accurately process information regarding soil erosion. Therefore, it is essential to confirm the credibility of these methods by investigating the results yielded by examinations compared with measured quantities taken from watersheds of Iran. The importance of the practical role of soil maps in evaluating erosion and sedimentation must also be considered. In this study, both MPSIAC and EPM were used to estimate erosion and sediment yield. Sediment measuring stations showed a rate of 2.74 t/ha per year; however, the MPSIAC model showed a rate of 1.56 t/ha per year and the EPM model showed a rate of 5.73 t/ha per year. Both the EPM and MPSIAC models were created in countries with climates and geology attributes that differ from those of Iran. Hence, the coefficients and factors affecting erosion do not correspond precisely to the conditions in Iran.

Keywords: Erosion, Gavrilovic method (EPM), MPSIAC, Qualitatively, Quantitatively, Sediment.

\section{INTRODUCTION}

The role of erosion and sediment yield in reducing soil fertility; soil waste; the filling of reservoirs; the obstruction of irrigation channels, streams, and rivers and the worsening of their states; and the contamination of downstream waters is undeniable. To prevent and reduce these consequences, soil, watershed, and sediment control measures are essential (Hakimkhani, 2002).

Today in most developing countries, population growth, the imbalance in the ratio of livestock to pastures, overuse of pastures and forests, and the unprincipled exploitation of forests, pastures, and farms have resulted in

\footnotetext{
${ }^{1}$ Maryam Pourkarimi, Department of Soil Science, Science and Research Branch, Islamic Azad University, Tehran, IRAN; Shahla Mahmoudi (corresponding author: smahmodi@ut.ac.ir), Department of Soil Science, Tehran University, Tehran, IRAN; Mohamadhasan Masihabadi, Soil and water Research Institute of Tehran, IRAN; Ebrahim Pazira, Department of Soil Science, Science and Research Branch, Islamic Azad University, Tehran, IRAN. Abolfazl Moeini, Department of watershed management, Science and Research Branch, Islamic Azad University, Tehran, IRAN.

Notes: The authors declare that they have no conflicts of interest. Authorship Form signed online.
} 
irreparable negative environmental, economic, and social consequences. Facts and figures attest to the critical state of Iran's water for reasons mentioned above. There has been a significant increase in the quantity and severity of flood and soil erosion in Iran since 1952 (Arekhi and Nazari, 2008; Ghodoosi, 2002).

To implement protection programs, determine measures to remedy problems in erosion and sediment control, and calculate and design the capacity of dams in reservoir construction, the annual mass of sediment yield in a watershed must be evaluated. If the statistics on the water flow rate and sediment yield of a watershed are available, the annual sediment yield can be calculated through statistical methods. The lack of such information about most of Iran's watersheds, however, calls for the implementation of suitable practical methods for estimating soil erosion and sediment yield (Refahi, 1999). The purpose of identifying soil hydrologic units is to determine runoff and probability of flooding in an area (Ahmadi, 2009).

The difficulties inherent in soil protection and sediment yield prevention, the lack of suitable equipment to estimate sedimentation, the incompatible statistics about most watersheds, and the adaptive methods implemented in Iran have resulted in a lack of appropriate, logical, and expected results in erosion and detriment evaluation. The MPSIAC and EPM models are two practical methods for evaluating erosion and sedimentation that have caught the attention of Iranian researchers. However, there have been no definite results about the accuracy of these models, only contradictory ones (Malekian, 2012).

Choosing a suitable model for determining erosion and sedimentation and calculating and drawing maps will yield important information that can be used in the management of renewable natural resources, soil conservation measures, dam designing, channel reservoirs, and land use projects. The soil erosion phenomenon is related to natural factors (morphology, soil type, climate, vegetation in the area, and human activities) (Hessel and Jetten, 2007; Vrieling et al., 2009). These factors include plowing, overgrazing, unsystematic farming, general overuse, and unprincipled management of the lands (Barovic et al., 2015).

According to the findings of some researchers (Tazioli, 2009; Tazioli et al., 2015), it is essential to have the effective load of sediment for several consecutive years to calibrate the erosion potential model. Modeling is a stable useful tool for estimating the erosion and discharge in a watershed with no available hydrometric information. Mathematical methods have been developed to predict erosion and sedimentation (Tazioli et al., 2015).

In a study of sedimentation in watersheds, Devenet et al. (2005) found that topographic data and satellite images in addition to prediction models are needed to achieve a relatively accurate determination of sediment yield and more executable results. Tangestani (2006) compared maps of sediment yield estimated by EPM and MPSIAC models and concluded that the MPSIAC model is more accurate. 
To calculate the potential sediment entering Breggia-Greggio delta system in Italy, Fanetti and Vezzoli (2007) made numerical and practical estimations in their study area. Tazioli (2009) used EPM to estimate the sedimentation in a semi-arid area and believed that the EPM method in GIS yielded better results than MPSIAC. Milevski (2008) studied the risks of soil erosion in the Bregalinica watershed in Macedonia using satellite images, EPM, and GIS and concluded that GIS is a very valuable tool for predicting the potential risks of soil erosion.

On studies done on the Tangkonesht watershed in northern Kermanshah state, which has a humid climate and vegetation cover varying from $25 \%$ to $55 \%$, Rastgou et al. (2006) achieved more accurate results using the MPSIAC method than with EPM.

Mohseni et al. (2011) studied the accuracy of EPM, MPSIAC, Geomorphology, and Hydrophysic models in estimating erosion and sediment yield at the Kasilian watershed in Mazandaran state. They found that the Geomorphology model was more suitable than the other models. The results of studies done by Moradi et al. (2011) on the Pourahmadi watershed in Hormozgan state showed that in some subbasins, the estimated erosion in high erosion areas was lower compared to the MPSIAC model.

Considering that the EPM method is implemented to estimate erosion potential in a watershed, the results achieved using this method in high erosion areas are less accurate (Moradi et al., 2011). Researchers such as Ahmadi et al. (2011), Amiri (2010), and Khodabakhsh et al. (2010) unanimously agree on their findings about the comparison between EPM and MPSIAC models.

By estimating sediment yield in the Forg watershed in southern Khorasan using the MPSIAC model and a modulation of GIS tools, Malekian et al. (2012) found that the results were significantly accurate. Overall, findings from research done inside and outside Iran has shown that a combination of traditional methods and modern tools like GIS and RS are able to satisfy requirements considering the lack of statistical information about most of Iran's watersheds.

Blinkov and Kostadinov (2010) evaluated the applicability of various erosion risk assessment methods for engineering purposes. Factors taken into consideration depended on scale, various erosion tasks, and various sector needs. The erosion potential method (EPM) was, according to them, most suitable on assessing catchment level for the watershed management needs in this region. It was created, developed, and calibrated in Yugoslavia (Gavrilovic, 1988).

This methodology is currently used in Bosnia and Herzegovina, Bulgaria, Croatia, the Czech Republic, Italy, Iran, Montenegro, Macedonia, Serbia, and Slovenia (Spalevic, 2014b; Kostadinov et al., 2014). The use of this methodology in research on runoff and the intensity of soil erosion has been demonstrated in Montenegro, specifically in the region of Polimlje (Spalevic et al., 2014a, 2014b, 2013a, 2013b, 2013c, 2013d, 2013e, 2013f, 2013g, 2012, 2011, 2008, 2007, 2004, 2003, 2001, 2000a, 2000b, 1999a, and 1999b; Fustic and Spalevic, 2000). 
The EPM is distinguished by its high degree of reliability in calculating sediment yield as well as reservoir sedimentation (Ristic et al., 2011).

\section{MATERIALS AND METHODS}

The study area (Fig. 1) of Mashhad-Chenaran is the biggest and the most important subbasin of Kashaf Rood. It extends 223989.7 acres, with geographical coordinates of $58^{\circ}-22^{I}$ to $60^{\circ}-7^{I}$ eastern longitude and 36 to $37^{\circ}-5^{\prime}$ northern longitude.

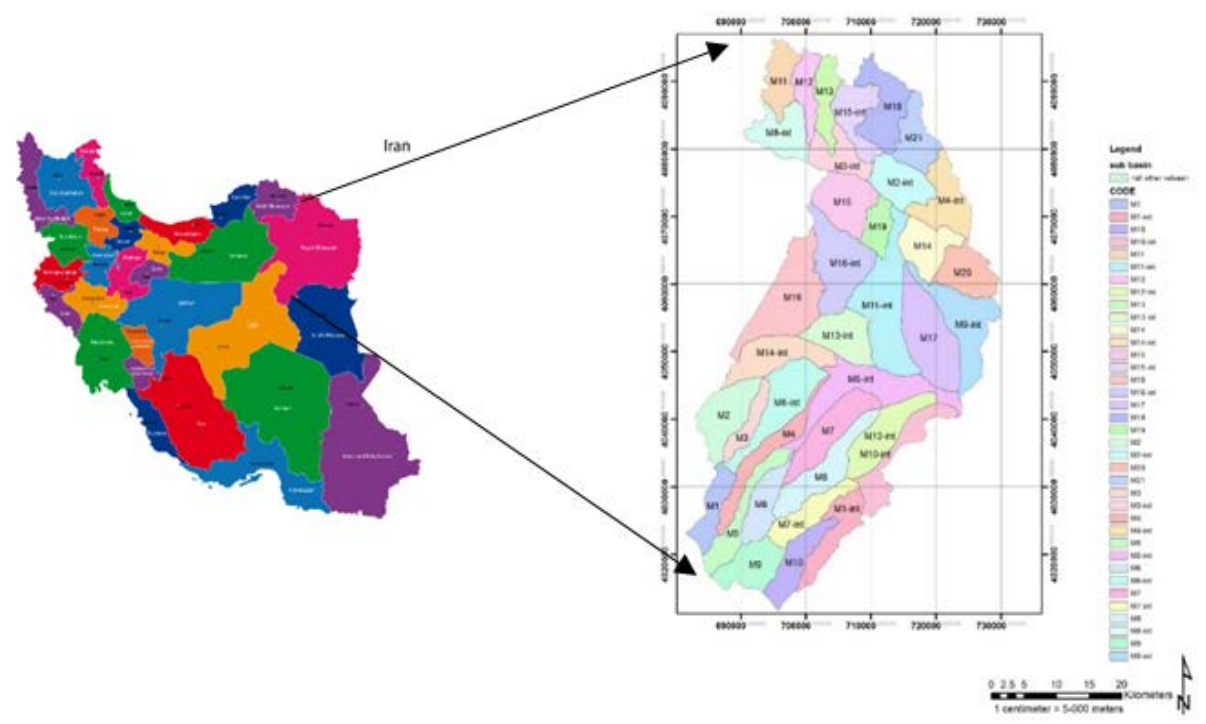

Figure 1: Study Area: Mashhad watershed phase II and intended area location in map of Iran

Mashhad-Chenaran is a relatively steep plain located between the HezarMasjed and Binaloud mountains. This plain is rectangular, $120 \mathrm{~km}$ in length and $28 \mathrm{~km}$ in width, and extends from northeast to southeast between the HezarMasjed and Binaloud mountains. The most important population centers of this plain are Mashhad, Chenaran, Shandiz, and Torghabeh. The population density is higher in the southern half of the plain.

Identifying soil hydrologic groups helps in estimating the runoff and flooding potential in an area. To calculate and identify soil hydrologic groups, the following measurements should be performed: soil gravel mass, depth, pores, texture and structure, and type and depth of the limiter layer. The influential factors affecting influx and speed of water in the hydrologic groups were determined based on the USA's soil conservation standards and then were divided into four hydrologic units.

The study area of Mashhad Urban Phase II was separated into 4 hydrologic units and 36 subbasins (Fig. 1, Table 3). Based on the results of recourse assessment and land ability, the area contains 7 main land types: mountains, hills, 
plateaus, upper terraces, piedmont plains, flood plains, gravel debris and fanshaped alluvial gravel, a miscellaneous type, and composite and non-arable lands. Paleozoic formations such as Lalun and Mila can be found in this area, and the middle section includes a quaternary deposit. Diversity of formations is one of the important factors for the constitution of different soil types and different geomorphological forms; hence, it rightfully has an effect on soil erosion and sedimentation.

The rainfall regime in this area is categorized as Mediterranean. The dry season coincides with summer, and the rainy season coincides with the cold season. Due to its low vegetation, this land is threatened by considerable erosion. Average rainfall amounts at the Mashhad station is 250 millimeters. Furthermore, snow in winter is one of the effective factors in reducing soil erosion.

Soil erosion and sedimentation in this study were determined by implementing a modified version of the Pacific Southwest Interagency Committee (PSIAC) (1968), about the evaluation of sediment yield in the southwestern USA that has an arid to semi-arid climate (Hadley, 1984). This model takes into consideration nine factors in erosion and sediment yield (Table 1): surface geology, soil, climate, runoff, topography, ground cover, land use, upland erosion, and channel erosion; because of this, it is widely used in Iran (Refahi, 1999).

Table1: The effective factors and their point's calculation formula in MPSIAC model

\begin{tabular}{|c|c|c|}
\hline $\begin{array}{l}\text { The effective } \\
\text { factors }\end{array}$ & $\begin{array}{c}\text { The points calculation } \\
\text { formula }\end{array}$ & Explanation Parameter \\
\hline Geology & $\mathrm{Y}_{1}=\mathrm{X}_{1}$ & X1: stone sensitive point \\
\hline Soil & $\mathrm{Y}_{2}=16.6 \mathrm{~K}$ & $\mathrm{~K}$ : erodibility factor in USLE \\
\hline Climate & $\mathrm{Y}_{3}=0.2 \mathrm{X}_{3}$ & $\begin{array}{l}\text { X3 : precipitation intensity with } \\
2 \text { year interval return }\end{array}$ \\
\hline Water runoff & $\mathrm{Y} 4=0.006 \mathrm{R}+10 \mathrm{Q}_{\mathrm{p}}$ & $\begin{array}{l}\mathrm{R}: \text { annual runoff depth }(\mathrm{mm}) \\
\mathrm{Q}_{\mathrm{p}}: \text { annual specific discharge } \\
\left(\mathrm{CmS} / \mathrm{km}^{2}\right)\end{array}$ \\
\hline Topography & $Y_{5}=0.33 \mathrm{~S}$ & S : average watershed slope (\%) \\
\hline $\begin{array}{l}\text { Land vegetation } \\
\text { cover }\end{array}$ & $\mathrm{Y}_{6}=0.2 \mathrm{X}_{6}$ & X6 : bare soil (\%) \\
\hline Land use & $\mathrm{Y}_{7}=20-0.2 \mathrm{X}_{7}$ & X7 : canopy cover (\%) \\
\hline Surface soil erosion & $\mathrm{Y}_{8}=0.25 \mathrm{X}_{8}$ & $\begin{array}{l}\text { X8 : points summation in BLM } \\
\text { model }\end{array}$ \\
\hline Gully erosion & $\mathrm{Y}_{9}=0.16 \mathrm{X}_{9}$ & $\begin{array}{l}\text { X9 : point of Gully erosion in } \\
\text { BLM model }\end{array}$ \\
\hline
\end{tabular}

The Erosion Potential Method (EPM) was presented in the former Yugoslavia to determine the percentage of soil erosion. This model was introduced in 1988 at an international conference in China. Results showed that by applying EPM, not only could erosion levels in a watershed, but also the 
quantity of sediment produced in the subbasin and comparative parts of the land could be determined. Factors affecting soil erosion in this model were: slope, lithology, erosion faces, and land use (Gavrilovic, 1988).

The steps to drawing a map are as follows (Figs. 2 and 3):

With EPM, four characteristics were investigated: the coefficient of watershed erosion, land use coefficient, rock and soil erosion sensitivity coefficient, and the average slope of the land area in units or in networks of the map. Considering that there are several effective layers in the EPM and MPSIAC models that are used to achieve erosion intensity and sediment yield maps, the first step is to overlap these layers. Then, by merging the data, the erosion state of the study area can be determined.

Georeferencing information layers; Matching watershed and subbasin boundaries in different layers;polygoning target units; Converting polygons to raster layers; Super positioning and calculating on raster layers (9 MPSIAC factors (Table 1) and the factors affecting EPM); Obtaining maps of erosion intensity based on the weight of each layer.

\section{RESULTS AND DISCUSSION}

The efficiency of the EPM and MPSIAC methods in estimating the soil erosion and sediment yield of phase two of the Mashhad urban watershed was compared. The findings presented in Tables 2 and 3 show that the sediment and erosion estimations done by both models are significantly different from the erosion reported by the hydrometric station.

Table 2: Erosion and sediment yeild of Mashhad second urban phase watershed

\begin{tabular}{|c|c|c|c|c|c|}
\hline \multirow{2}{*}{$\begin{array}{c}\text { Area } \\
\text { (Hectare) }\end{array}$} & \multicolumn{2}{|c|}{ Sediment (ton/ha.year) } & \multicolumn{2}{c|}{ Erosion (ton/ha.year) } \\
\cline { 2 - 6 } & $\begin{array}{c}\text { Hydrometric } \\
\text { station }\end{array}$ & MPSIAC & EPM & MPSIAC & EPM \\
\hline 223989.7 & 2.74 & 1.56 & 5.73 & 3.19 & 9.45 \\
\hline
\end{tabular}

Results of the one sample test also showed that the estimations of both models have noteworthy differences with reports from the hydrometric station. By taking into consideration the incompatible statistics and database in some stations, the sediment rate estimated by the MPSIAC method was determined to be more accurate than that of EPM. The comparison of the estimation by EPM and the actual erosion calculated at the location indicated that EPM overestimates the value of erosion compared to the MPSIAC method (Tables 2 and 3). In the MPSIAC model, more factors are taken into consideration for estimating erosion (Table 1). The values estimated by the MPSIAC model in all subbasins were a great deal smaller compared with the values estimated by the EMP model (Table 2). 
Table 3: Erosion and sediment yeild of Mashhad second urban phase watershed

\begin{tabular}{|c|c|c|c|}
\hline \multirow{2}{*}{ Sub basin } & \multirow{2}{*}{ Area $\left(\mathrm{m}^{2}\right)$} & \multicolumn{2}{|c|}{ Erosion (ton/ha.year) } \\
\hline & & MPSIAC & EPM \\
\hline M1-int & 48811001.09 & 2.98 & 7.64 \\
\hline M2-int & 53220952.54 & 7.36 & 18.80 \\
\hline M3-int & 41687233.37 & 4.36 & 17.42 \\
\hline M4-int & 61814704.09 & 7.72 & 9.78 \\
\hline M5-int & 95548948.09 & 1.70 & 2.16 \\
\hline M1 & 38031119.77 & 4.27 & 12.05 \\
\hline M2 & 64490828.47 & 1.80 & 8.53 \\
\hline M3 & 27175854.66 & 2.00 & 7.16 \\
\hline M6-int & 78248369.32 & 1.51 & 4.29 \\
\hline M4 & 51449433.58 & 2.78 & 9.28 \\
\hline M5 & 49677914.63 & 3.96 & 12.92 \\
\hline M6 & 45456422.64 & 3.70 & 7.72 \\
\hline M7 & 66903109.61 & 1.56 & 9.02 \\
\hline M8 & 68146942.07 & 2.53 & 9.62 \\
\hline M9 & 52994801.19 & 4.62 & 12.32 \\
\hline M7-int & 45305655.07 & 3.19 & 10.51 \\
\hline M10 & 48886384.88 & 4.10 & 7.16 \\
\hline M11 & 41008779.30 & 4.81 & 13.20 \\
\hline M8-int & 53107876.87 & 5.55 & 18.90 \\
\hline M12 & 34111162.93 & 5.84 & 14.70 \\
\hline M13 & 36862671.10 & 5.72 & 16.44 \\
\hline M20 & 53145568.76 & 3.48 & 27.50 \\
\hline M15 & 65433125.79 & 4.85 & 24.56 \\
\hline M9-int & 85560596.51 & 2.98 & 8.03 \\
\hline M16 & 111869537.64 & 1.44 & 4.55 \\
\hline M10-int & 53183260.65 & 1.95 & 7.38 \\
\hline M11-int & 120576364.86 & 2.73 & 5.55 \\
\hline M17 & 100298126.57 & 1.74 & 2.88 \\
\hline M12-int & 64415444.69 & 1.42 & 4.95 \\
\hline M13-int & 57857055.35 & 1.36 & 1.47 \\
\hline M14-int & 66903109.61 & 1.41 & 3.58 \\
\hline M21 & 48622541.63 & 3.64 & 4.92 \\
\hline M15-int & 50017141.66 & 4.25 & 13.10 \\
\hline M18 & 67355412.32 & 3.97 & 9.29 \\
\hline M16-int & 90121315.53 & 2.23 & 11.14 \\
\hline M14 & 52806341.72 & 6.38 & 10.43 \\
\hline M19 & 29022757.41 & 3.90 & 10.62 \\
\hline
\end{tabular}


One reason for this significant difference is that EMP predicts the erosion potential of the watershed, and in locations with a high degree of erosion, the accuracy of the model decreases.

When choosing a model, it is important to pay attention to its origins. As previously mentioned, the EPM model was first designed and applied in the former Yugoslavia. Since this method is widely used in erosion and sediment yield estimation in Iran, there must be a high level of similarity between the study area and the location for which the model was designed in order for the model to achieve an accurate estimation. Therefore, if the climate of the study area is different from Yugoslavia, the coefficients must be calibrated based on the climatic differences between the study area and the original location.

The findings of the present study agree with those of studies done by Abedini et al. (2013), Ahmadi et al. (2011), Amiri (2010), and Khodabakhsh et al. (2010) in Iran. The application of GIS and RS would not only reduce the expenses and time compared to traditional methods, it would also increase accuracy in estimating erosion. Therefore, the use of up-to-date satellite images will help increase the accuracy of estimations by a great deal. To use the EPM model under different climatic conditions, it is recommended that the model be calibrated by the climate coefficients of the climate in the study area. In addition, by changing the work-units and making them more homogenous, the results will be more accurate in studying the erosion maps in both models (EPM and MPSIAC).

While choosing a method, it is very important to place significance on its place of origin. Studies done on soil erosion and sediment yield estimation in Iran have worked particularly with the EPM model which, as mentioned before, was designed and demonstrated first in the former Yugoslavia. The former Yugoslavia has been divided into the countries of Bosnia and Herzegovina, Macedonia, Croatia, Montenegro, Serbia, and Slovenia on the west of the Balkan Peninsula, and the area has completely different climatic conditions and vegetation from the study area in the present research.

In the study area, the precipitation follows the Mediterranean regime; summer is the dry season, and rainfall occurs during winter. About $40 \%$ of rainfall happens during one month of winter. The temperature of the area is influenced by the air masses and height of the area. The average annual temperature of the Mashhad Urban Watershed Phase II is $10.7^{\circ} \mathrm{C}$ and fluctuates between $-0.7^{\circ} \mathrm{C}$ and $21.7^{\circ} \mathrm{C}$ during the year. The average humidity ranges from $51.6 \%$ to $37.9 \%$ in July and reaches $66.9 \%$ in February.

Maximum wind speeds at the synoptic stations of Golmakan and Mashhad are 74 and 45 knots, respectively, and the wind direction is $290^{\circ}$ north and $310^{\circ}$ north, respectively. The average evapotranspiration calculated at the Zoshk evaporative station using the Penman method is $1356.2 \mathrm{ml}$. Rainfall in the whole basin equals $305.2 \mathrm{ml}$. According to hyetograph curves, the humid months are from mid-November to mid-May, and the rest of the year is dry. The climate of 
the region is identified as arid/semi-arid to semi-humid by the Domarten method and semi-cold arid to cold arid by the Emberger method.

The dominant vegetation in the research area consists mostly of thorny Astralagus and thorny/unthorny perennial herbaceous bushes. Due to unchanging growth conditions and the lack of diversity of species in the area, a total of 9 vegetation types were found, 3 of which were scattered in the Binaloud heights and the rest in the Hezar-Masjed heights. The Binaloud heights include numerous slopes and valleys within which agriculture and horticulture are common activities. In higher elevations, due to the construction of multiple roads, the access routes of the nomadic tribes to the heights have been either destroyed or covered in vegetation with little to no palatability value.

Unlike the Binaloud heights, there are fewer villages in the Hezar-Masjed heights located in Mashhad Urban Watershed Phase II, and environmental degradation in this area is more significant. The slopes are covered mostly with rocks and sparse vegetation. A relatively deep valley leads the watershed of this area to Mashhad Urban Watershed Phase II, and except for the Moqmenj river valley which is covered in farms, apple orchards, and other agricultural products, vegetation is sparse; lands are even degraded or covered with invasive or inedible plants.

The upper elevations of the Hezar-Masjed heights are generally covered by Astragalus meschedensis, Artemisia kopetdaghensis, Rosa persica, Cousinia adenostegia, Acantholimon erinaceum, Artemisia scoparia, Acanthophyllum sordidum, Acanthophyllum spinosum, and Acantholimon scirpinum. The countries of the former Yugoslavia, despite slight differences, all generally include dense forest vegetation, vast lush meadows, and forests even in the mountainous areas.
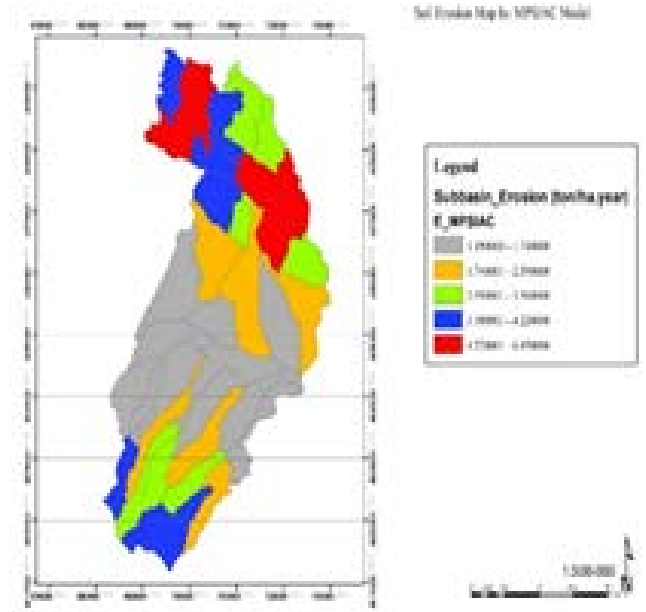

Figure 2: Soil erosion map using (EPM)
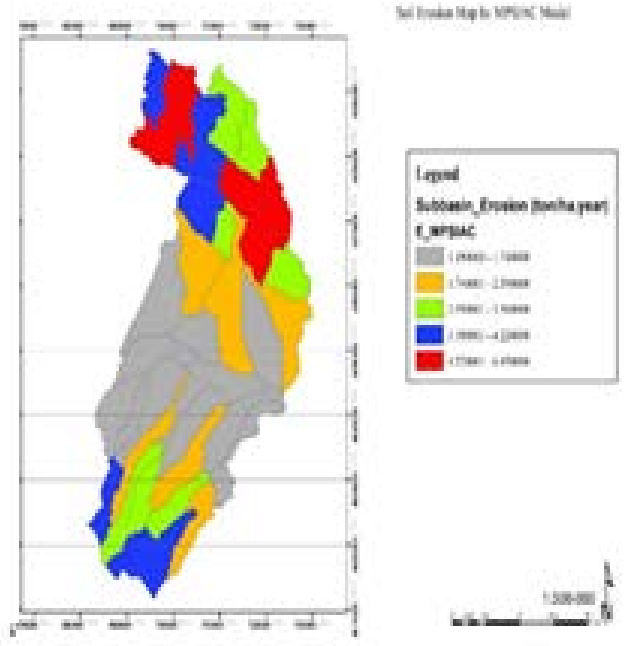

Figure 3: Soil erosion map using MPSIAC model 


\section{CONCLUSIONS}

As mentioned before, the vast differences between the climatic conditions and vegetation in the study area and the place of origin of the Gavrilovic method (the former Yugoslavia) can explain the Very high estimations of the model in soil erosion and sediment yield estimation in the study area. Based on the findings of this study, models do not have the same results in all lands. Therefore, for selecting a model, there should be the most similarity between the model domain area and the study area. The results showed that the estimates in the Gavrilovich model are higher; it is likely that large rocky outgrowths in a large part of the research area are one of the reasons for the high estimates, which further explains the choice; More research is needed, such as selecting more homogeneous units than hydrological units.

\section{REFERENCES}

Abedini, M. S, Shabrang. A, Esmaeili., (2013): The Evaluation of soil Erosion and sediment Meshkindasht watershed to EPM method., Geography and Development Quarterly, vol,11. No. 30, 87-100.

Ahmadi, H., (2011): Applied Geomorphology (Water Erosion), Vol. 1, 7th Edition, University of Tehran Press, Tehran, Iran.

Ahmadi. H., M. R. Servati., A. M. Noormohamady, (2011): Sediment And Erosion Estimation Using EPM And MPSIAC, Using Geomorphological Method And GIS In Baghareh (Torbat e Heydarieh) Catchment Basin, Journal of Geographical Science, (Issue 7).

Ahmadi. H., J. Ghodoosi. B. Mohseni,. R. Tahmasebi., (2011): Assessing the accuracy and effectiveness of models for EPM, MPSIAC, geomorphology and hydro estimation of erosion and sedimentation basin province kasilian. Geography and Development Quarterly, vol,9. No. 22, 107-127.

Amiri. F., (2010): Compression of Efficiency of MPSIAC and EPM Models to Estimate Soil Erosion and sedimented Yield (Case Study: Ghareh Aghach Watershed), Iranian Journal of Dynamic Agriculture , (Issue 2).

Arekhi,S. and R. Nazari. 2008. Zoning erosion intensity and sediment yield using MPSIAC in GIS (Case study: Ilam catchment). Jornal of Iranian Water Research, 2(3), 77-81.

Barovic.G, Navessilva.M.L, Batista.P.V.G, Vujacic.D, Soaressouza.W, Avanzi. J.S, Behzadfar.M and Spalevic.V (2015). Estimation of Sediment Yield Using the Intero Model in the S1-5 Watershed of the Shirindareh River Basin, Iran, Agriculture \& Forestry, Vol.61 Issue 3:333-243, 2015, Podgorica.

Blinkov, I. and Kostadinov, S. (2010): Applicability of various erosion risk assessment methods for engineering purposes, BALWOIS 2010 Conference - Ohrid, Republic of Macedonia. 25 - 29 May 2010.

Devenet. J and J.Poesen. 2005. Predicting Soil erosion and sediment yield at the basin scale. Scale issue and semi-quantitation Model Earth Science. 20, 1-31.

Fanetti, D., Vezzoli, L., (2007): Sediment input and evolution of lacustrine deltas: The Breggia and Greggio Rivers case study (Lake Como, Italy). Quaternary International, 173-174, 113-124. 
Gavrilovic, Z. (1988): The use of an empirical method production and transportation in unstudied or torrential streams. Proceeding of International Conference on River Regime 18-2 May 1988. Published by John Eiley and Sons Paper 12. 411-422.

Ghodoosi, J. (2002): Global pattern in watershed management. National Conference of Field Management- Soil Erosion and Development Arak: Central Province Agricultural Research and Natural Resource Center Iran.

Hadley, R. F. (1984): Measuring and Predicting Soil erosion. In, R. F. Hadley and D.E. Walling. Eds. Erosion and sediment yields some methods of measurement and modeling. Geo Books, Norwich. UK. 1-14.

Hessel, R. and Jetten, V. (2007): Suitability of Transport Equations in Modelling Soil Erosion for a Small Loess Plateau Catchment. Engineering Geology, 91, 56-71. http://dx.doi.org/10.1016/j.enggeo.2006.12.013

Khodabash. S., (2010): Comparison of erosion and sediment yield estimation in Sezar sub basin (Dez drainage basin) by MPSIAC and EPM empirical methods, using GIS, Iranian Journal of Geology, Issue 12.

Kostadinov S., Zlatic M., Dragicevic S., Novkovic I., Kosanin O., Borisavljevic A., Lakicevic M., Mlađan D. (2014): Anthropogenic influence on erosion intensity changes in the Rasina River watershed - Central Serbia. Fresenius Environmental Bulletin 01/2014; 23(1a): 254-263.

Malekian. A., M. Dehghani. H. Ghasemi., (2012): Priority Places reduce flood and erosion control operations using fuzzy logic (Case Study: Watershed Fourg), Journal of Watershed Management Research. Vol. 66. No 1. 2012. Pp. 73-88.

Milevski, I.,(2008): Estimation of Soil Erosion Risk in the Upper Part of Bregalnica Watershed-Republic of Macedonia, Based on Digital Elevation Model and Satellite Imagery, 5th International Conference on Geographic Information System (IGIS) 2-5 July 2008 at Fatih University in Istanbul, Turkey.

Rafahi, H., (1999):Water Erosion and Conservation, 5th Edition, University of Tehran Press, Tehran, Iran.

Rastgou, S. Ghahraman, B. Sanaei Nejad, H. Davari, K. \& Khodashenas, S.R. (2006): Estimation of erosion and sediment in the Tangh Konesht basin by PASIAC and EPM models using by GIS. Journal of science and Technology of agriculture and natural Resources, Vol. 10, No. 1, PP. 91-105.

Ristic, R., Radic, B., Vasiljevic, N. and Nikic, Z. (2011): Land use change for flood protection - a prospective study for the restoration of the river Jelasnica watershed. Bulletin of the Faculty of Forestry103: 115-130.

Spalevic, V., Curovic, M., Simunic, I., Behzadfar, M, Tanaskovic, V. (2014): Land degradation, land use and soil erosion: the case of Montenegro. Watch Letter: Land Issues in the Mediterranean Countries 28 (1), 58-62.

Spalevic, V., Radanovic, D., Behzadfar, M, Djekovic, V., Andjelkovic, A., Milosevic, N. (2014): Calculation of the sediment yield of the Trebacka Rijeka, Polimlje, Montenegro. Agriculture and Forestry 60 (1), 259-272.

Spalevic, V., Djurovic, N., Mijovic, S., Vukelic-Sutoska, M., Curovic, M. (2013): Soil Erosion Intensity and Runoff on the Djuricka River Basin (North of Montenegro). Malaysian Journal of Soil Science, Vol. 17: p.49-68. ISSN: 1394-7990. Spalevic, V., Grbovic, K., Gligorevic, K., Curovic,M., and Billi, P. (2013): Calculation of runoff and soil erosion on the Tifran watershed, Polimlje, North-East of Montenegro. Agriculture and Forestry, Vol. 59, Issue 4: p.5-17. ISSN 0554-5579 (Printed), ISSN 1800-9492 (Online). 
Spalevic, V., Curovic, M. Tanaskovik, V., Oljaca, M., Djurovic, N. (2013): The impact of land use on soil erosion and run-off in the Krivaja river basin in Montenegro. The First International Symposium on Agricultural Engineering, 4th - 6th October 2013, Belgrade-Zemun, Serbia, VI: 1-14.

Spalevic, V., Nyssen, J., Curovic,M., Lenaerts, T., Kerckhof, A., Annys, K. Van Den Branden, J., Frankl, A. (2013): The impact of land use on soil erosion in the river basin Boljanska rijeka in Montenegro. In proceeding of the 4th International Symposium “Agrosym 2013” (3-6 October, 2013, Jahorina, Bosnia). Key note speakers, p. 54-63.

Spalevic, V., Curovic, M., Uzen, N., Simunic, I., Vukelic-Shutoska, M. (2013): Calculation of soil erosion intensity and runoff in the river basin of Ljesnica, Northeast of Montenegro. In proceeding of the 24th International ScientificExpert Conference on Agriculture and Food Industry, Sarajevo, Bosnia and Herzegovina.

Spalevic, V., Curovic, M., Tanaskovik, V., Pivic, R., Djurovic, N. (2013): Estimation of soil erosion intensity and runoff in the river basin ofBijeli Potok, Northeast of Montenegro. In proceeding of the 1st International Congress on Soil Science, XIII Congress of Serbian Soil Science Society "SOIL - WATER PLANT”,October, 2013. Belgrade, Serbia.

Spalevic, V., Simunic, I., Vukelic-Sutoska, M., Uzen, N., Curovic, M. (2013): Prediction of the soil erosion intensity from the river basin Navotinski, Polimlje (Northeast Montenegro). Agriculture and Forestry, Vol. 59, Issue 2: p.9-20. ISSN 0554-5579 (Printed), ISSN 1800-9492 (Online).

Spalevic, V., Mahoney, W., Đurovic, N., Üzen, N., Curovic, M. (2012): Calculation of soil erosion intensity and maximum outflow from the Rovacki river basin, Montenegro. Agriculture and Forestry, Vol. 58, Issue 3: p.7-21. ISSN 0554-5579 (Printed), ISSN 1800-9492 (Online).

Spalevic, V. (2011): Impact of land use on runoff and soil erosion in Polimlje. Doctoral thesis, 260p, Faculty of Agriculture of the University of Belgrade, Serbia.

Spalevic, V., Curovic, M., Borota, D., Fustic, B. (2008): Soil erosion in the River Basin Zeljeznica, area of Bar, Montenegro. Agriculture and Forestry, Vol. 54, Issue 1-4: p.5-24. ISSN 0554-5579 (Printed), ISSN 1800-9492 (Online).

Spalevic, V., Curovic, M., Povilaitis, A. (2007): Conditions of soil erosion in the Komaraca river basin, North-East of Montenegro. Paper presented at conference Erosion and Torrent Control as a Factor in Sustainable River Basin Management, Belgrade.

Spalevic, V., Curovic, M., Povilaitis, A., Radusinovic, S. (2004): Estimate of Maximum Outflow and Soil Erosion in the Biogradska River Basin. Monographs, No.1, Biodiversity of the Biogradska Gora National Park, ed. V. Pesic.pp. 1-20, Department of Biology of the University of Montenegro, Podgorica.

Spalevic, V., Seker, G., Fustic, B., Ristic, R., Sekularac, G. (2003): Conditions of erosion of soil in the drainage basin of the Crepulja - Lucka River. Paper presented at, Natural and Socioeconomic effects of Erosion Control in Mountainous Regions, pp. 287-292, Banja Vrujci, Srbija, Faculty of Forestry, Belgrade, World Ass. of Soil\&Water Conservation.

Spalevic, V., Fustic, B., Soskic, S., Ristic, R. (2001): The estimate of maximum outflow and soil erosion intensity in the Vinicka river basin with application of computer graphic methods. Agriculture and Forestry, Vol. 47, Issue 3-4: p.95-104. ISSN 0554-5579 (Printed), ISSN 1800-9492 (Online). 
Spalevic, V., Fustic, B., Jovovic, Z., Curovic, M.,Spalevic, B., Popovic, V. (2000): Characteristics of erosion processes and proposal of land reclamation measures in the drainage basin of the Sekularska river. Agriculture and Forestry, Vol. 46, Issue 3-4: p.2-18. ISSN 0554-5579 (Printed), ISSN 1800 -9492 (Online).

Spalevic, V., Dlabac, A., Spalevic, B., Fustic, B., Popovic, V. (2000): Application of computer - graphic methods in the research of runoff and intensity of ground erosion - I program "River basins". Agriculture and Forestry, Vol. 46, Issue 1-2: p.19-36. ISSN 0554-5579 (Printed), ISSN 1800-9492 (Online).

Spalevic, V. (1999): Application of computer-graphic methods in the studies of draining out and intensities of ground erosion in the Berane valley. Master thesis, Faculty of Agriculture of the University of Belgrade, Serbia, 135p.

Spalevic, V., Dubak, D., Fustic, B., Jovovic, Z., Ristic, R. (1999): The estimate of the maximum outflow and soil erosion intensity in the Kaludra River basin. Acta Agriculturae Serbica IV(8): 79-89.

Tangestani, M. 2006, comparison of EPM and PSIAC models in GIS for erosion and sediment yield assessment in a semi-arid environment: Afzar catchments, Fars Province, Iran.Journal of Asian earth sciences, vol.27, P.585- 597.

Tazioli, A., 2009, Evaluation of Erosion in Equipped Basins: Preliminary Results Comparison Between the Gavrilovic Model and Direct Measurements of Sediment Transport, Environ Geol, Vol. 5, No. 56: 825-831.

Tazioli A., Mattioli A., Nanni T., Vivalda P.M. (2015): Natural hazard analysis in the Aspio equipped basin. Engineering geology for Society and Territory, Vol. 3:431535. Doi 10.1007/978-3-319-09054-2_98.

Vrieling, A., Jong, S.M., Sterk, G. and Rodrigue, S.C. (2009): Timing of Erosion and Satellite Data: A Multi-Resolution Approach to Soil Erosion Risk Mapping. International Journal of Applied Earth Observation and Geo information, 10, 267281. 